\title{
Measuring Physical access to primary health care facilities in Gambella Region (Western Ethiopia)
}

\author{
Pier Lorenzo Fantozzi ${ }^{a}$, Giuseppe Baracca ${ }^{b}$, Fabio Manenti ${ }^{\mathrm{b}}$, Giovanni Putoto ${ }^{\mathrm{b}}$ \\ ${ }^{a}$ University of Siena Department of Physics, Earth and Environmental Sciences, Via laterina 8, 53100, Siena Italy- \\ fantozzip@unisi.it \\ ${ }^{b}$ Doctors with Africa Cuamm, Via San Francesco 126, Padova Italy - international@cuamm.org \\ * Corresponding author
}

\begin{abstract}
As part of the project "More equity and quality of health services in Gambella, Gambella Region", financed by the Italian Agency for Development Cooperation (AICS) and implemented by the Italian NGO Doctors with Africa CUAMM (Padua, Italy) a geographic database of the distribution of health facilities of Gambella Region (western Ethiopia) was created. This data collection was carried out in two missions carried out in February 2018 and November-December 2019. It allowed a mapping of the access roads and the location of health facilities using Geomatic Approaches and related technologies (Remote Survey, Field Survey, GPS, GIS). The field work has allowed the investigation in 11 Waredas (i.e. districts) with the census of 3 primary hospitals, 26 health centres and 121 HPs and related road access by car or, in case of inaccessibility of vehicles, by foot or boat.The final result of this work is the availability of a detailed cartographic picture of the geographical distribution of Health Facilities (HFs) in order to support the modern decision-making tools to be adopted for the distribution of human and instrumental resources. As an example we describe a network analysis performed by ESRI TM Netwok Analyst which showed the importance of this approach to remodel a more efficient referral system.
\end{abstract}

Keywords: GIS, Network Analysis, Health Facility

\section{Introduction}

This study was implemented into the framework of the project, "MORE QUALITY AND EQUITY OF HEALTH SERVICES IN GAMBELLA, GAMBELLA REGION, ETHIOPIA", financed by the Italian Agency for Development Cooperation (IADC) and executed by the Italian NGO Doctors with Africa CUAMM.

The general goal of the program is to improve medical of the mother and baby in order obtain a lasting and concrete result in reducing maternal and infant mortality. For the case study the project was focused on the challenging access to the obstetric emergency referral system in the project area as a proxy for all kinds of emergencies, either surgical or medical. The field work was carried out in two stages: in February 2018 and November - December 2019 with the target of mapping health facilities and relative access roads using the Geographical Information System technology (GIS). Data elaboration was realized in preliminary stage in 2018 and the completed analysis with Map Atlas compilation and diffusion to the ethiopian partners was realized in September 2020. The study area, surrounding the Gambella town, is typical rural area of African countries with scattered villages, low density of population, very few asphalted roads and general lacking of public transport.
In the Gambella Region, as in many African countries, detailed updated cartography at an operational scale (i.e. 1: $10.000-1: 25.000)$ is present only in urban areas, while in rural areas there is only a 1:50000 scale cartography (dating back to the several decades ago) that does not report the updates of the communication routes built recently. Even the Health Facilities map and the relative catchment area was not available for the Gambella Region, so that frequently the Local Officiers of the Health Centre trace manually a sketch map for their competence area in order to support their work for vaccination or other needs (Figura 1).

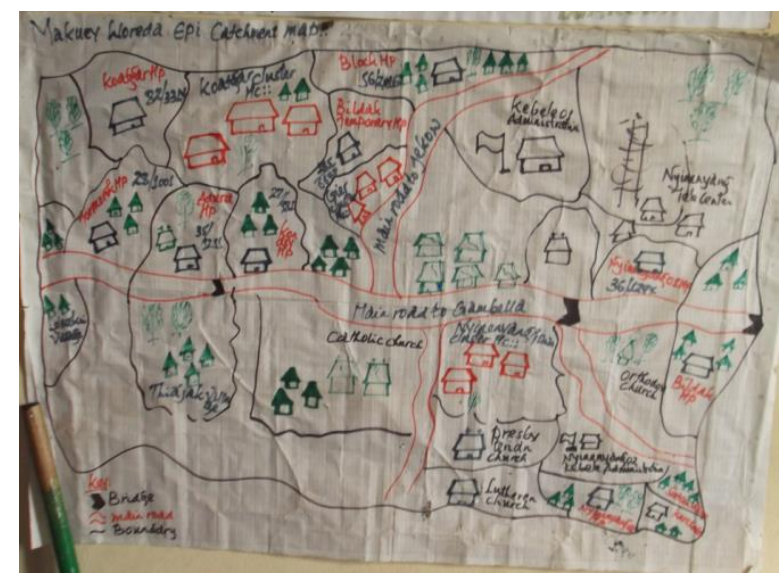

Figura 1. Manual sketch map drown by the Local Officers for the Health Centre catchment area. 
It follows that for the purposes of programming medical services and decision support there is not rational and geographic reference framework that allows adequate and efficient programming of services. To overpass this limitation in order to fulfil the project targets a team from the Department of Physics, Earth and Environmental Sciences from the University of Siena (Italy) assured the specialized technical support both for field survey and in data elaboration for GIS analysis and map production (for references about the use of GIS in health system see Mc Lafferty SL (2003) and Fogliati P. et al., 2015). In this way the use of GIS analysis was intended to create a database referring to the type, location and spatial distribution of health facilities in the study area and to measure distance and travel time from the peripheral health facilities to the higher referral level. This data set can now be utilized to identify areas that are under-served and to propose valuable alternatives that could be implemented within this resource limited setting, in order to maximize effectiveness of the ambulance referral system.

\section{Contribution of the study: aim and objectives}

\subsection{Aim}

Scope of this project "More equity and quality of health services in Gambella, Gambella Region" was to appraise the diverse sustainable existing choices that could be implemented, in order to improve the obstetric emergency referral system performance for reducing the coverage gaps, in a context with scarce resources.

\subsection{Objectives}

The specific objective were: 1- to create a geographical database of the type, location and spatial distribution of health facilities for the whole region of Gambella; 2emphasize the use of the spatial analysis (using ESRI ${ }^{\mathrm{TM}}$ Network Analyst ${ }^{\mathrm{TM}}$ ) within a subset of the collected data, the Woreda of Gambella, Abobo and Gambella Town, in order to shows how is possible identify under-served areas, because of their excessive distance and/or access time from the reference centre, and consequently propose advantageous alternative options that could be implemented within this resource limited setting. This case study, related to a subset of the collected data (see in the follow the section 6.2), examines only the spatial components of the health care system accessibility related to the obstetric emergency referral system.

\section{Background}

\subsection{Government and administration in Ethiopia}

Ethiopia is a federal parliamentary republic with a Prime Minister serving as head of government. The 1995 Ethiopian Constitution created nine Regional States and two City Administrations which are divided into Woredas (Districts) and Kebeles (Sub-districts). A Woreda is the basic decentralized administrative unit presided by an elected administrative council.

\subsection{The National Health System in Ethiopia}

The National Health System (NHS) in Ethiopia has a pyramidal shape made of three-tiers health care delivery system (Federal Democratic Republic of Ethiopia, 2010): level one is a Woreda/District health system comprised of a primary hospital (to cover 60,000-100,000 people), Health Centres, HCs, (1/15,000-25,000 population) and their satellite Health Posts, HPs, (1/3,000-5,000 population) connected to each other by a referral system. The primary hospital, HCs and HPs form a Primary Health Care Unit (PHCU). Level two is a General Hospital covering a population of 1-1.5 million people; and level three is a Specialized Hospital covering a population of 3.5-5 million people (HSDP-IV 2010/2015, $\mathrm{MoH})$. HPs should mainly provide preventive services and promoting clients' positive attitude toward health besides of basic curative services (malaria treatment, cure of common infections and ORS treatment for diarrheal, etc.). More complex curative and rehabilitative care is provided at Health Centre and Hospital levels according to their specific capability, as per national minimum standards, to manage patients according to diagnosis and therapy complexity.

\section{Study area}

The survey area cover the main part of Gambella Region, in the westernmost part of the Ethiopia, along the boundary of Sudan and South Sudan (Figura 2).

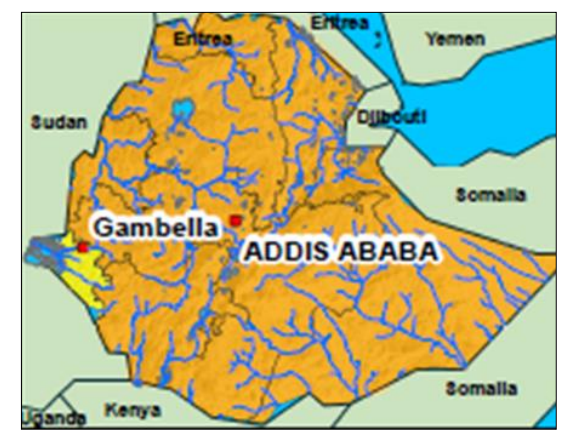

Figura 2. In yellow the Gambella Region

The study area extend from $33^{\circ}, 00^{\prime}$ to $35^{\circ}, 39^{\prime}$ East longitude and from $6^{\circ}, 32^{\prime}$ to $8^{\circ}, 71^{\prime}$ North Latitude. According to "Gambella, 2019 Pledge Progress Report (UNHCR Ethiopia, 2019), the region has a population of about 409,000 inhabitants (2015 population projection, https://www.citypopulation.de/Ethiopia.html).

The altitude in the study area range from 300 up to 2300 meters above the sea level. The natural morphology of the region is characterized in the eastern part by of the Ethiopian plateau that to the west gradually slopes towards a region of undulating plains where the vegetation of the savannah prevails, with large humid area flooded during rainy season.

The climate is tropical with two seasons, rainy from February-March up to September-October and dry season for the remaining months of the year. Annual rainfall 
averages about $600 \mathrm{~mm}$ while the minimum/ maximum temperatures are approximately $21^{\circ} \mathrm{C}$ and $35^{\circ} \mathrm{C}$ respectively. In the lowland during the raining season the flooding are very frequent causing interruption of the connections between the villages and severe limitation of the sanitary assistance. In the northern area flows the Baro river that cross Gambella Town, the regional capital. The Baro rivers and main tributaries are navigable and marks the border with South Sudan. These river network connecting Gambella Region to South Sudan is one of the main communication way for refugees transit. Gambella region hosts the largest refugee population in Ethiopia, over 300000 settled in 7 refugee camps. This region is divided into 13 Wareda, having a total land area ca $26,000 \mathrm{~km} 2$. The Region is one of the poorest in the country, with $35.3 \%$ of the population positioned in the lowest wealth quintile. The $32.2 \%$ of females and $22.3 \%$ of males are illiterates; only $3 \%$ of females and $7 \%$ of males respectively have an education above the secondary school, as reported in the Ethiopia Mini Demographic and Health Survey (EMDHS 2014).

\section{Methods and tools}

\subsection{Preliminary work}

The preliminary works was carried out in the Geographic Information System Laboratory of the Department of Physics, Earth and Environmental Sciences of the University of Siena (Italy) analyzing the satellite images of the Gambella Region. The target of this stage was prepare a preliminary maps that could assist the field work and for planning and realization of field activities; in this way we compared the name of cities, villages and sites of location of the HF's supplied by the Gambella Town operative staff of CUAMM, with the available sources of data and particularly satellite images and the available maps in web GIS (i.e. Google Earths ${ }^{\mathrm{TM}}$, Google Maps $^{\mathrm{TM}}$, Bing ${ }^{\mathrm{TM}}$, Open Street Map ${ }^{\mathrm{TM}}$ ). Unfortunately we found a very scarce correspondence between the list of the available place names included in the source of data and the name of the HF's. Given this scarcity of available data the large part of the work was based to the fieldwork relating to the direct survey of the geographic position of the HFs and relative access roads. The final result of the preliminary work was a sketch map of the available place names of the region and relative possible access roads; this map was used for planning the field work described in following chapter.

\subsection{Field works}

In order to operate in safety conditions and avoid any possible access problems, the survey agenda was discussed and approved by, the Country Manager of CUAMM. The technical equipment, supplied by the University of Siena, included a Dell Latitude rugged tablet (with two lithium batteries and included GPS), and 5 Garmin Etrex 10 portable GPS to be assigned to the
Extension Worker duties. Further equipment (laptops, cameras, hard disks, GIS platform (ArcGISTM etc), was used as normal procedure for managing the collected spatial data. The Field work has been organized using the four-wheel drive, with the support of the local staff composed by a CUAMM and local assistants. The use of boat was necessary for survey facilities placed along the rivers. The GPS equipment managed ArcGIS ${ }^{\text {TM }}$ platform allowed us a real-time capturing of data: during the motion (car, boat or walking) the parameter was set in order to acquire a detailed position, and this position was recorded in a feature attribute table that can be elaborated to define the travelled roads (Figura 3).

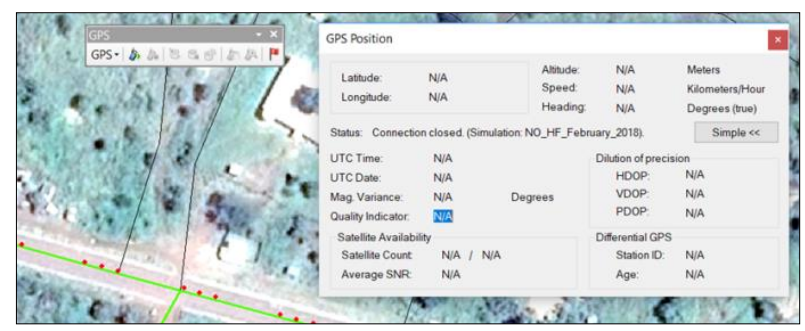

Figura 3. ArcMap ${ }^{\mathrm{TM}}$ interface with GPS tracks and satellite images.

Particularly during the field work carried out in November - December 2019 the study area was interested by large flooded areas so in several case we used boat to reach the remote HF's not accesible by other way (car or walking) (Figura 4, Figura 5 ).

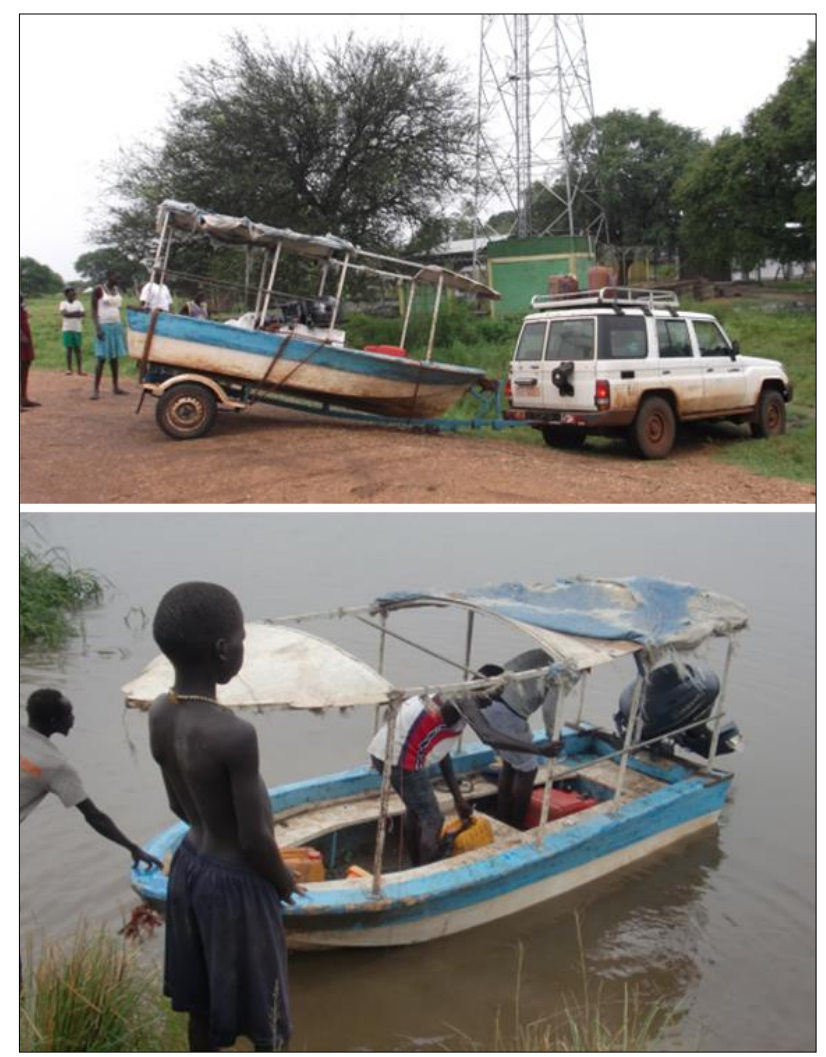

Figura 4. Use of boat for reaching facilties not accessible during rainy season 
Once arrived at the HFs site, we recorded data relatively to the geographic coordinates and other ancillary data related to the availability of electrical power, water, name of responsible person and phone number. Pictures with relative coordinates were collected in any $\mathrm{HF}$, more than 1500 geotagged pictures were collected during the fieldworks.

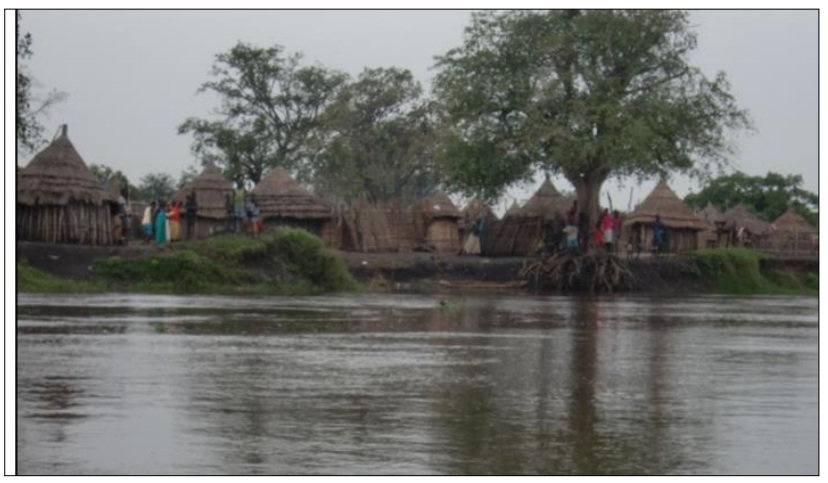

Figura 5. Example of surveyed Health Post in located in village along the Jilo river.

During the fieldwork, in selected HFs, we assigned a portable GPS device to the Extension Worker, asking him/her to walk along the path from the community/village to the referral HFs (Figura 6).

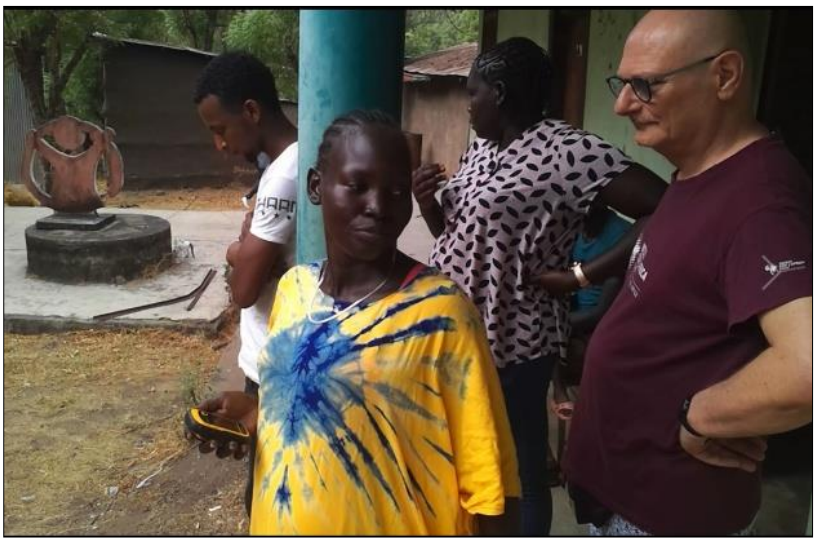

Figura 6. A brief training for the Extension Worker on the use of the device was supplied by the CUAMM Staff

The field work results was an essential part for the preparation of the subsequent processing of data and the final report.

\subsection{Compilation of Map Atlas}

The field work allowed the investigation in 11 Waredas with the census of 3 primary hospitals, 26 health centres and 121 HPs and related road access by car or in case of inaccessibility of vehicles by foot or boat. All the data was collected in a A4 size atlas map with including more the 250 original maps. The maps are relative to each wareda and its HF's with the access road (Figura 7). For the surveyed Wareda, the atlas map include other detailed map for each health centres and relative HPs and detailed report for each HFs (Figura 8 and Figura 9).

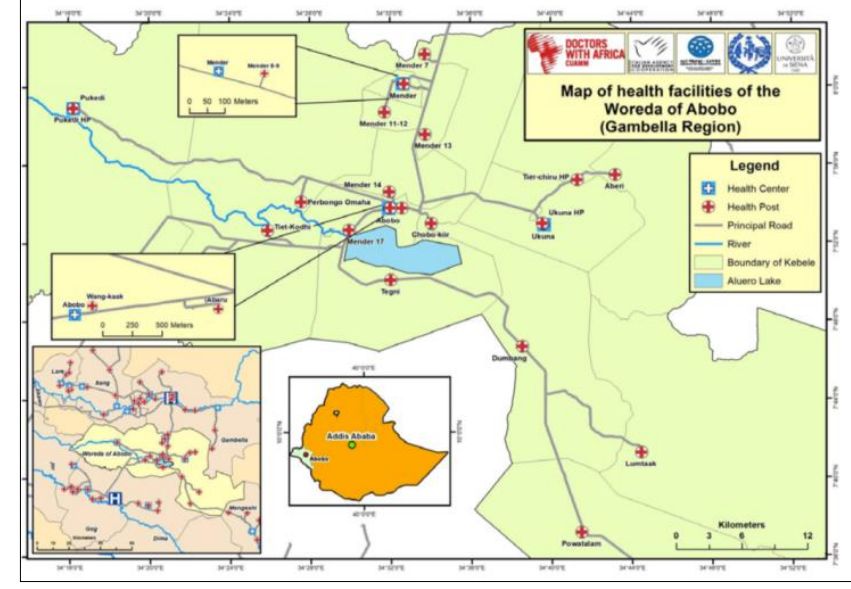

Figura 7. Example of the wareda Health Facilities map.

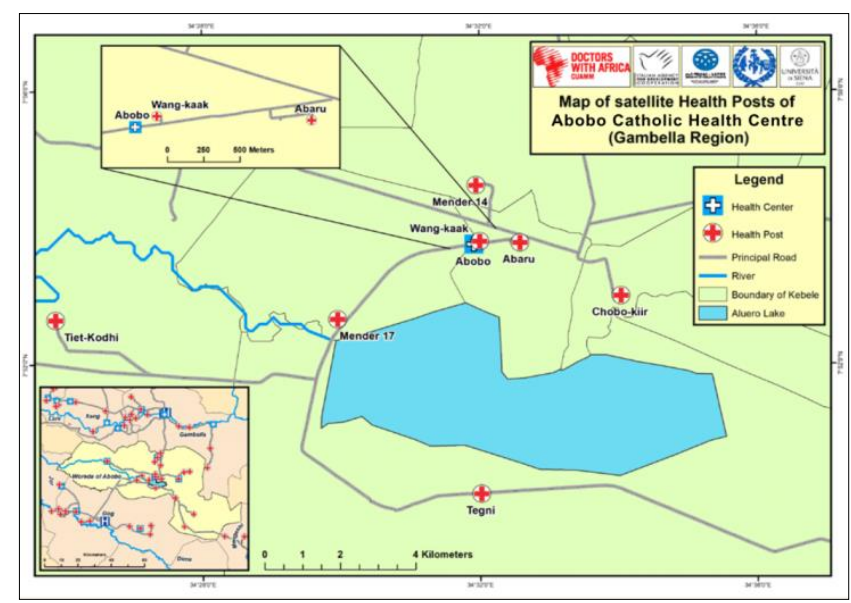

Figura 8. Example of the Health centre and relative Health Post map.

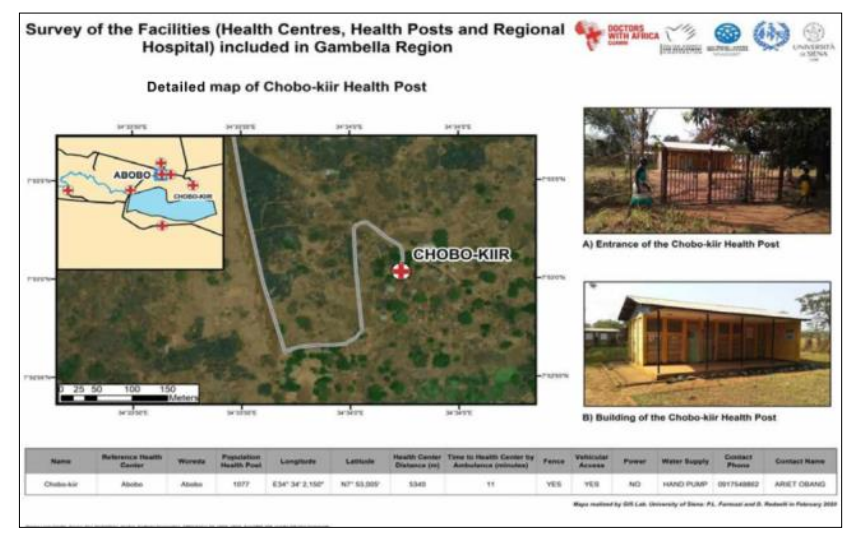

Figura 9. Example of resuming report realized for each facilities and included in a 250 pages Atlas Map.

In order to facilitate the diffusion of the results, all the data were collected and represented in a synoptic and map (Figura 10).

\subsection{Elaboration of different scenarios}

On the basis of the collected data we elaborated a different scenarios for support to maternal and newborn 


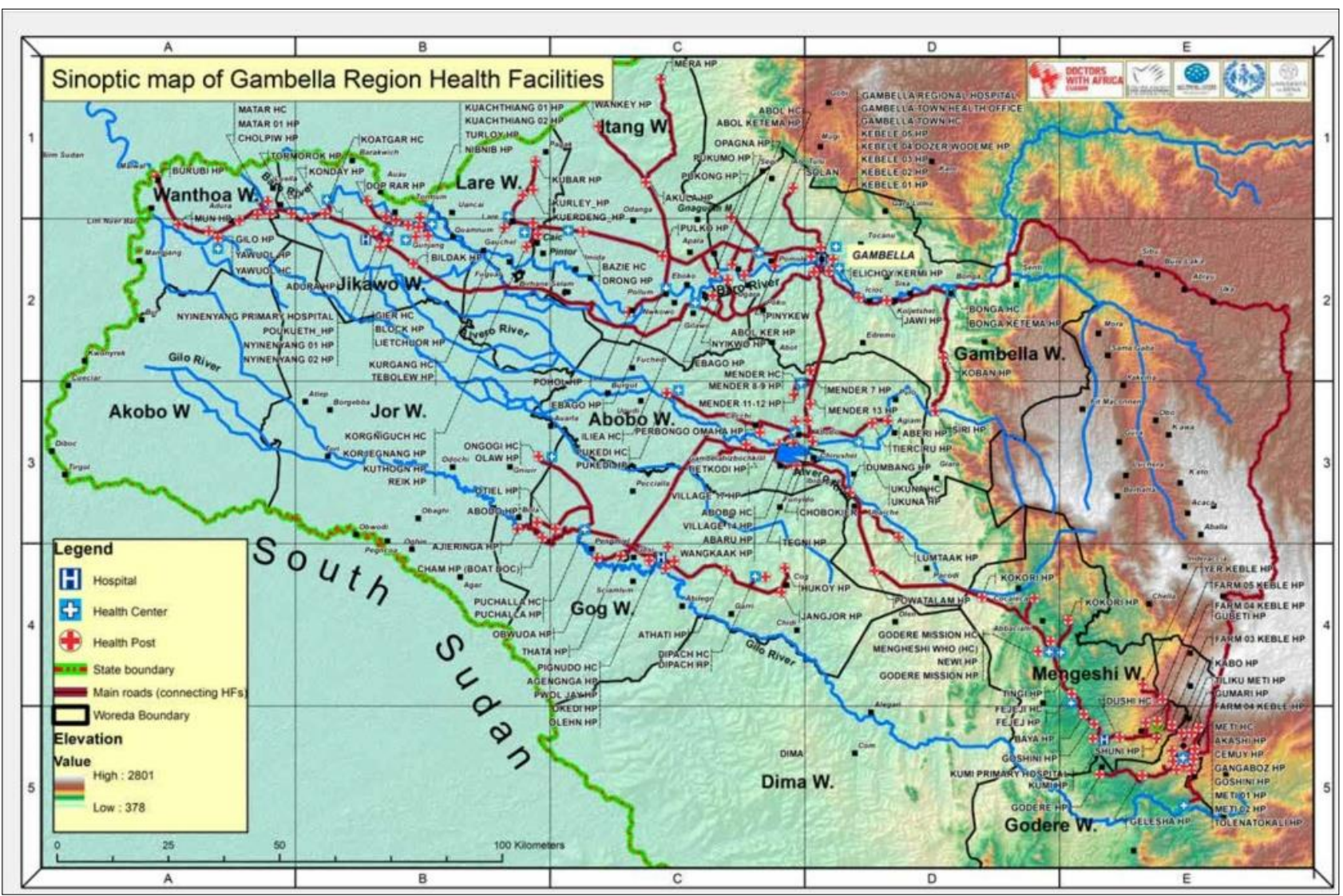

Figura 10

community health services provided by the first level HCs in Gambella, Gambella town and Abobo Districts. The result of these elaboration are descrive in the follows as use of data set for planning a rational ambulance referral system

\subsubsection{Short description of obstetric and neonatal} packages offered by the health system

Obstetric emergencies happen at any time during pregnancy. In accordance with the kind of occurring problem the emergency in developing countries is taken in charge by the system at two levels. At HC, with the package called Basic Emergency Obstetric Neonatal Care (BEmONC), which provides parenteral antibiotics, uterotonic drugs, anti-convulsion drugs, manual removal of placenta, removal of retained products, assisted vaginal delivery and neonatal resuscitation; whereas at hospital level the package is fulfilled with Cesarean Section and blood transfusion and is called Comprehensive Emergency Obstetric Neonatal Care (CEmONC) (WHO, UNFPA, UNICEF, AMOD 2009).

\subsubsection{Transportation time as limiting factor}

When quality health services provided by the system at facility level are available the limiting factors to reduce mortality and morbidity are distance and time needed to transport the patients (McKinnon B. et al. 2014). The cut off point, that makes the difference for the needed transportation time is estimated at two hours (UNFPA 2004; Maine D. et al. 1997) especially for taking care of hemorrhage, one of the most important and frequent complications of the pregnancies. The idle time due to difficulty in communication for the net black out and/or other delays have to be included within the two hours.

\subsubsection{The referral system how it is presently organized} in the study area

Both the Woreda of Gambella and the Woreda of Abobo has an ambulance provided by the Federal Ministry of Health $(\mathrm{FMoH})$ and are parked at the Woreda Health Office (WoHO) in Abobo and in Abol HC in Gambella, at disposition when called. The system is organized to transport the emergencies from the HPs to the HC of reference and from here to the Gambella Regional Hospital if the case requires. Using the Network analysis the travel time between the facilities and hospital (Figura 11), has been calculated and discussed as follows.

The Woreda of Gambella Town encompasses five urban Kebeles, which are not affected from the problem of delayed reference to emergency care as all Kebeles have easy access to Gambella HC and Gambella Hospital. The ambulance parked in Gambella Town HC provides the referral service. The Woreda of Gambella is provided with two ambulances parked in Abol and Bonga HCs. 


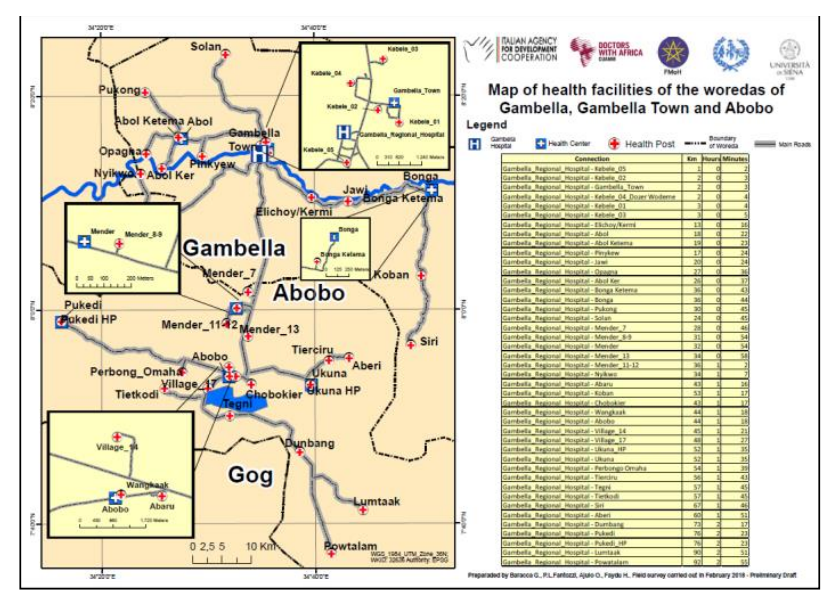

Figura 11. Example of a Health Facilities and space-time tabular data elaborated by the use on Network Analyst ${ }^{\mathrm{TM}}$ application.

Abol is situated at the northwest of the Woreda, while Bonga is located at the opposite southeast, see the Figura 11. The health facilities which refer BEmONC cases to Abol $\mathrm{HC}$ are far from it less than two hours, are six over seven $(86 \%)$. One HP of the Abol catchment area is beyond two hours: (Niykwo), while another is at threshold (Solan), as shown in Table 1. In case the emergency is CEmONC the patient cannot be managed at $\mathrm{HC}$ level and the case has to be referred to the Hospital in Gambella. The travel time increases and the coverage of health facilities, including Abol $\mathrm{HC}$, becomes six over eight $(75 \%)$, as the HPs of Solan and Niykwo are afar more than two hours for the referral system, see table 2 .

\begin{tabular}{ccccc}
$N^{\circ}$ & $\begin{array}{c}\text { Health Facility Name of } \\
\text { Abol catchment area }\end{array}$ & $\begin{array}{c}\text { Time in minutes } \\
\text { from Abol to HF }\end{array}$ & $\begin{array}{c}\text { Time in minutes to } \\
\text { return from HF to Abol }\end{array}$ & $\begin{array}{c}\text { Total time to } \\
\text { Gambella Regional } \\
\text { Hospital }\end{array}$ \\
\hline 1 & Abol - Abol Ketema & 1 & 2 & 24 \\
\hline 2 & Abol - Pinykew & 12 & 23 & 45 \\
\hline 3 & Abol - Opagna & 14 & 28 & 50 \\
\hline 4 & Abol - Abol Ker & 15 & 30 & 52 \\
\hline 5 & Abol - Pukong & 23 & 45 & 67 \\
\hline 6 & Abol - Solan & 57 & 115 & 137 \\
\hline 7 & Abol - Nyikwo & 89 & 178 & 200 \\
\hline & Abol - Gambella & & & 22 \\
\hline & Hospital & & \\
\hline
\end{tabular}

Table 1. List of health facilities referring to Abol $\mathrm{HC}$ in the Woreda of Gambella, their time in minutes to travel to the HC of reference and additional time to reach Gambella Regional Hospital

The health facilities referring BEmONC cases to Bonga $\mathrm{HC}$, which are far from it less than two hours are four over five $(80 \%)$. One HP, Siri, is far beyond two hours for the referral system, seeTable 3.The coverage of $\mathrm{CEmONC}$ referral cases, including Bonga $\mathrm{HC}$, is five over six $(83 \%)$. The HP of Siri is still out of reach for an effective referral (Table 2).

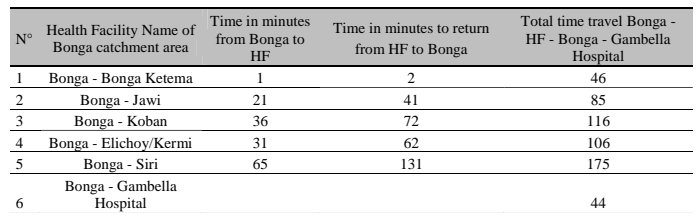

Table 2. List of health facilities referring to Bonga HC, their time in minutes to travel to the $\mathrm{HC}$ and additional time to reach Gambella Regional Hospital.
Data collected during the field activities in the Woreda of Abobo are shown in Table 3

\begin{tabular}{|c|c|c|c|c|}
\hline $\mathbf{N}^{\circ}$ & $\begin{array}{l}\text { Health Facility Name of } \\
\text { Abobo catchment area }\end{array}$ & $\begin{array}{l}\text { Time in minutes } \\
\text { from Abobo to HF }\end{array}$ & $\begin{array}{l}\text { Time in minutes to } \\
\text { return from HF to } \\
\text { Abobo }\end{array}$ & $\begin{array}{c}\text { Total time to } \\
\text { Gambella } \\
\text { Regional } \\
\text { Hospital } \\
\end{array}$ \\
\hline 1 & Abobo - Wangkaak & 1 & 2 & 140 \\
\hline 2 & Abobo - Abaru & 3 & 5 & 143 \\
\hline 3 & Abobo - Village 14 & 8 & 16 & 154 \\
\hline 4 & Abobo - Tegni & 27 & 53 & 191 \\
\hline 5 & Abobo - Lumtaak & 93 & 187 & 325 \\
\hline 6 & Abobo - Powatalam & 97 & 193 & 331 \\
\hline 7 & Abobo - Gambella Hospital & 0 & 0 & 138 \\
\hline 8 & Abobo - Tietkodi & 27 & 55 & 193 \\
\hline 9 & Abobo - Village 17 & 9 & 18 & 156 \\
\hline 10 & Abobo - Dumbang & 59 & 24 & 137 \\
\hline 11 & Abobo - Chobokier & 11 & 21 & 159 \\
\hline $\mathbf{N}^{\circ}$ & $\begin{array}{l}\text { Health Facility Name of } \\
\text { Pukedi catchment area }\end{array}$ & $\begin{array}{l}\text { Time in minutes } \\
\text { from Abobo to } \mathrm{HF}\end{array}$ & $\begin{array}{l}\text { Time in minutes to } \\
\text { return from HF to } \\
\text { Pukedi }\end{array}$ & $\begin{array}{c}\text { Total time to } \\
\text { Gambella } \\
\text { Regional } \\
\text { Hospital } \\
\end{array}$ \\
\hline 12 & Abobo - Perbongo Omaha & 26 & 44 & 208 \\
\hline 13 & Abobo - Pukedi HP & 70 & - & 208 \\
\hline 14 & Abobo - Pukedi Health Center & 70 & - & 208 \\
\hline $\mathrm{N}^{\circ}$ & $\begin{array}{l}\text { Health Facility Name of } \\
\text { Ukuna catchment area }\end{array}$ & $\begin{array}{l}\text { Time in minutes } \\
\text { from Abobo to HF }\end{array}$ & $\begin{array}{l}\text { Time in minutes to } \\
\text { return from HF to } \\
\text { Ukuna }\end{array}$ & $\begin{array}{l}\text { Total time to } \\
\text { Gambella } \\
\text { Regional } \\
\text { Hospital } \\
\end{array}$ \\
\hline 15 & Abobo - Ukuna HP & 31 & 3 & 129 \\
\hline 16 & Abobo - Ukuna Health Center & 32 & - & 127 \\
\hline 17 & Abobo - Aberi & 47 & 15 & 157 \\
\hline 18 & Abobo - Tierciru & 39 & 7 & 141 \\
\hline $\mathrm{N}^{\circ}$ & $\begin{array}{l}\text { Health Facility Name of } \\
\text { Mender catchment area }\end{array}$ & $\begin{array}{l}\text { Time in minutes } \\
\text { from Abobo to HFF }\end{array}$ & $\begin{array}{l}\text { Time in minutes to } \\
\text { return from HF to } \\
\text { Mender }\end{array}$ & $\begin{array}{l}\text { Total time to } \\
\text { Gambella } \\
\text { Regional } \\
\text { Hospital } \\
\end{array}$ \\
\hline 19 & Abobo - Mender 8-9 & 35 & - & 89 \\
\hline 20 & $\begin{array}{l}\text { Abobo - Mender Health } \\
\text { Center }\end{array}$ & 35 & - & 89 \\
\hline 21 & Abobo - Mender 7 & 38 & 3 & 95 \\
\hline 22 & Abobo - Mender 11-12 & 43 & 8 & 105 \\
\hline 23 & Abobo - Mender 13 & 23 & 12 & 89 \\
\hline
\end{tabular}

Table 3. List of health facilities in the Woreda of Abobo, their time in minutes to travel to the Health Center of reference and additional time to reach Gambella Regional Hospital.

The BEmONC referral system coverage in Abobo HC catchment area is eight over ten $(80 \%)$, in Pukedi is two over two $(100 \%)$, in Ukuna is three over three $(100 \%)$ and for Mender is four over four (100\%).

For the CEmONC cases the picture change dramatically due to the limiting factor of delay caused for transporting patients from the Health Centers, where the patients have been clinically stabilized, to the Hospital in Gambella. Only Mender health center is located to a distance shorter than two hours travel time to Gambella. In this scenario the referral system coverage for the whole Woreda of Abobo decreases to only five facilities over twenty-three $(22 \%)$.

\subsection{Strategies to improve the referral system performance}

\section{1) Adapting the official norms defined at central level to the local context}

In accordance with the norms defined at central level, the referral system loop starts at the ambulance parking place, from here it goes to the facility where the patient is admitted and after the ambulance travels directly to the Health Center of reference where the BEmONC cases are taken in charge in loco. If the clinical case is a CEmONC the patient is stabilized in loco with an appropriated treatment and than transported to the Hospital.

Introducing new norms: a) presence on board of kit to stabilize the patient and b) midwife or MNCH (Maternal, Newborn and Child Health) staff able to diagnostic cases of CEmONC to allow transportation directly to Gambella 
Hospital from the peripheral health facility in order to avoid the delay caused by travelling to Health center, we can achieve a little increase of coverage and some important spare of time as shown in Table 4 and Table 5 versus Table 1 and Table 2. For Abol Health Center catchment area the facilities covered increase of one unit i.e. Solan, but the travel time decreases consistently for Nyikwo (Table 4).

\begin{tabular}{|c|c|c|c|c|c|}
\hline $\mathbf{N}^{\circ}$ & $\begin{array}{l}\text { Health Facility Name of } \\
\text { Abol catchment area }\end{array}$ & $\begin{array}{l}\text { Time in } \\
\text { minutes from } \\
\text { Abol to HF }\end{array}$ & $\begin{array}{l}\text { Time in minutes } \\
\text { to return from HF } \\
\text { to Abol }\end{array}$ & $\begin{array}{l}\text { Total time travel } \\
\text { Abol - HF - Abol } \\
\text { Gambella } \\
\text { Hospital } \\
\end{array}$ & $\begin{array}{l}\text { Time from HF to } \\
\text { Gambella } \\
\text { Hospital } \\
\text { avoiding Abol }\end{array}$ \\
\hline 1 & Abol - Abol Ketema & 1 & 2 & 24 & 24 \\
\hline 2 & Abol - Pinykew & 12 & 23 & 45 & 36 \\
\hline 3 & Abol - Opagna & 14 & 28 & 50 & 50 \\
\hline 4 & Abol - Abol Ker & 15 & 30 & 52 & 52 \\
\hline 5 & Abol - Pukong & 23 & 45 & 67 & 67 \\
\hline 6 & Abol - Solan & 57 & 115 & 137 & 102 \\
\hline 7 & Abol - Nyikwo & 89 & 178 & 200 & 156 \\
\hline 8 & Abol - Gambella Hospital & & & 22 & 22 \\
\hline
\end{tabular}

Table 4. List of health facilities and time needed to transport the CEmONC cases directly from the facility to the Hospital in Gambella, avoiding Abol Health Center.

For the catchment area of Bonga the coverage does not change but also here there is a consistent reduction of travel time for Elichoy/Kermi and Jawi, which is an evident benefit for cases in need of urgent care in specialized setting (Table 5).

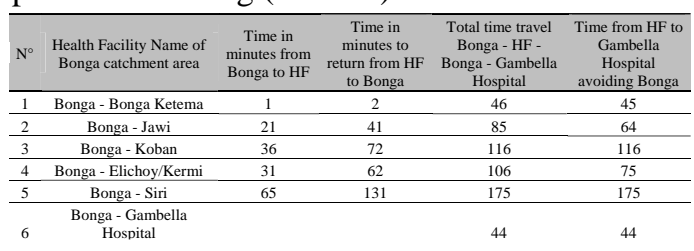

Table 5. List of health facilities and time needed to transport the CEmONC cases directly from the facility to the Hospital in Gambella, avoiding Bonga Health Center.

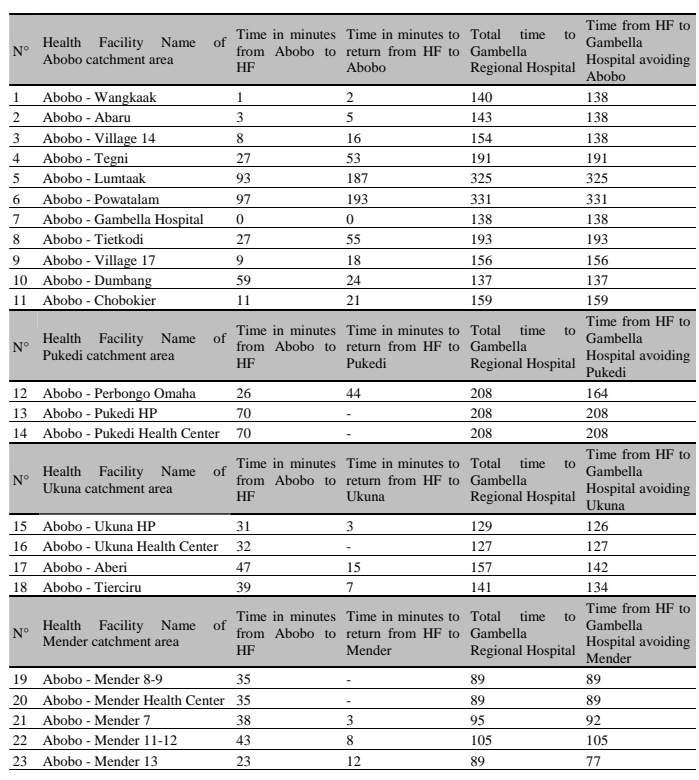

Table 6. List of health facilities and time needed to transport the CEmONC cases directly from the Health Posts to the Hospital in Gambella, avoiding Pukedi, Ukuna, Mender and Abobo Health Centers Bonga.
The previuous Table 6 shows the theoretical reduction in travel times when applying the alternative strategy of adapting the official norms for the referral system to the facilities in the Woreda of Abobo. For the Health Posts in the catchment area of Abobo and Ukuna Health Centers the time reduction is very much insignificant due to the geographical bottleneck of the access roads. For the Health Posts depending on Pukedi Health Center there is only Perbongo Omaha, which benefits the reduction of forty-four minutes travel time, the remaining facilities are in the same situation of those depending from Abobo and Ukuna due to the access roads bottleneck.

2) Integrating the referral system by ambulance with maternity waiting homes situated in crucial health centers.

The second scenario forecasts a mix of interventions i.e. integration of obstetric referrals by ambulance with the offer of lodging pregnant women at MWHs (Maternity Waiting Homes) in proximity of Health Centers, destined to host selected pregnant women at risk for complications, well in advance before the foresees date of delivery. Ideally, the best sites to organize MWHs are the Health Centers of Abobo, Bonga and the Gambella Hospital. By doing so, it is possible to overcome the excess of travel time to and from the farthest health facilities: Powtalam, Dumbang and Lumtaak for Abobo; Siri and Koban for Bonga; Solan and Nyikwo for Abol. The following tables Table 7, Table 8 and Table 9 show the effects of implementing such a scenario. The mix ambulance referral system plus MWH- in Gambella Hospital can assure full coverage for all health facilities under competence of Abol Health Center (Table 7).

\begin{tabular}{|c|c|c|c|c|}
\hline & $\begin{array}{l}\text { Health Facility Name of } \\
\text { Abol catchment area }\end{array}$ & $\begin{array}{l}\text { Time in munutes to } \\
\text { travel one way from } \\
\text { Abol to } \mathrm{HF}\end{array}$ & $\begin{array}{l}\text { Time in munutes to } \\
\text { return travel from } \mathrm{HF} \text { to } \\
\text { Abol }\end{array}$ & $\begin{array}{l}\text { Time } \\
\text { Gambella } \\
\text { Regional } \\
\text { Hospital }\end{array}$ \\
\hline 1 & Abol - Abol Ketema & 1 & 2 & 24 \\
\hline & Abol - Pinykew & 12 & 23 & 45 \\
\hline 3 & Abol - Opagna & 14 & 28 & 50 \\
\hline & Abol - Abol Ker & 15 & 30 & 52 \\
\hline & Abol - Pukong & 23 & 45 & 67 \\
\hline \multicolumn{5}{|c|}{ Pregnant women in need for BEmONC or CEmONC are already admitted at the Mother Wayting Home } \\
\hline & Gambella Hospital (Solan) & & & 0 \\
\hline & $\begin{array}{l}\text { Gambella } \\
\text { (Nyikwo) }\end{array}$ Hospital & & & 0 \\
\hline
\end{tabular}

Table 7. The table shows travel times to Gambella Hospital when pregnant women at risk for BEmONC or CEmONC from Solan and Nyikwo Health Posts are admitted well in advance at the Gambella Hospital Mother Waiting Home.

The mix -ambulance referral system plus MWH- in Bonga Health Center can assure too a complete coverage for all health facilities under competence of the Health Center (Table 8).

\begin{tabular}{|c|c|c|c|c|}
\hline $\mathrm{N}^{\circ}$ & $\begin{array}{l}\text { Health Facility Name of Bonga } \\
\text { catchment area }\end{array}$ & $\begin{array}{l}\text { Time in } \\
\text { minutes from } \\
\text { Bongal to } \mathrm{HF}\end{array}$ & $\begin{array}{l}\text { Time in minutes } \\
\text { to return from } \\
\text { HF to Bonga }\end{array}$ & $\begin{array}{l}\text { Total time travel Bon } \\
\text { HF - Bonga } \\
\text { Gambella Hospital }\end{array}$ \\
\hline 1 & Bonga - Bonga Ketema & 1 & 2 & 46 \\
\hline 2 & Bonga - Jawi & 21 & 41 & 85 \\
\hline 3 & Bonga - Elichoy/Kermi & 31 & 62 & 106 \\
\hline \multicolumn{5}{|c|}{ Pregnant women in need for BEmONC or CEmONC are already admitted at the Mother Wayting Home } \\
\hline 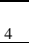 & $\begin{array}{l}\begin{array}{l}\text { Bonga - (Siri) - Gambella } \\
\text { Hospital }\end{array} \\
\end{array}$ & & $2=$ & 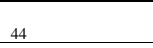 \\
\hline 5 & $\begin{array}{l}\text { Bonga - (Koban) - Gambella } \\
\text { Hospital }\end{array}$ & & - & 44 \\
\hline
\end{tabular}

Table 8. The table shows travel times to Gambella Hospital when pregnant women at risk for BEmONC or CEmONC from Solan and Nyikwo Health Posts are admitted well in advance at the Gambella Hospital Mother Waiting Home. 
The mix ambulance referral system plus MWH in Abobo Health Center does not assure the full coverage of the Woreda, neither for the BEmONC nor for the CEmONC cases. See Table 9. However, for some health facilities i.e. Tegni, Lumtaak, Powtalam, Tietkodi, Dumbang and Chobokier, the decrease of travel time from Abobo to Gambella Hospital is on average one hundred minutes. The same occurs for the facilities referring to Pukedi Health Center: i.e. Pukedi Health Post and Perbongo Omaha, the decrease in travel time is on average seventy minutes. For the facilities referring to Ukuna Health Center there is only one Health Post with a reduced travel time (nineteen minutes) to Gambella Hospital i.e. Aberi. The case of Mender Health Center is even counterproductive with increased travel times of fortyfive minutes on average.

\begin{tabular}{|c|c|c|c|c|}
\hline $\begin{array}{l}\mathrm{N}^{\circ} \begin{array}{l}\text { Health Facility Name of } \\
\text { Abobo catchment area }\end{array} \\
\text { a }\end{array}$ & $\begin{array}{l}\text { Time in munutes } \\
\text { to travel from } \\
\text { Abobo to } \mathrm{HF}\end{array}$ & $\begin{array}{l}\text { Time in munutes } \\
\text { to return from HF } \\
\text { to Abobo }\end{array}$ & $\begin{array}{l}\text { Total time } \\
\text { Gambella } \\
\text { Hospital }\end{array}$ & $\begin{array}{l}\text { Time from } \\
\text { to MWH in Abobo } \\
\text { to Gambella } \\
\text { Hospital }\end{array}$ \\
\hline Abobo - Wangkaak & 1 & 2 & 140 & 138 \\
\hline 2 Abobo - Abaru & 3 & 5 & 143 & 138 \\
\hline 3 Abobo - Village 14 & 8 & 16 & 154 & 138 \\
\hline $\begin{array}{l}4 \\
\text { Abobo - Tegni } \\
\end{array}$ & 27 & 53 & 191 & 138 \\
\hline 5 Abobo - Lumtaak & 93 & 187 & 325 & 138 \\
\hline 6 Abobo - Powatalam & 97 & 193 & 331 & 138 \\
\hline 7 Abobo - Gambella Hospital & 0 & 0 & 138 & 138 \\
\hline $\begin{array}{ll}8 & \text { Abobo - Tietkodi } \\
\end{array}$ & 27 & 55 & 193 & 138 \\
\hline $9 \quad$ Abobo - Village 17 & 9 & 18 & 156 & 138 \\
\hline 10 Abobo - Dumbang & 59 & 117 & 230 & 138 \\
\hline 11 Abobo - Chobokier & 11 & 21 & 159 & 138 \\
\hline $\begin{array}{l}\mathrm{N}^{\circ} \begin{array}{l}\text { Health Facility Name of } \\
\text { Pukedi catchment area }\end{array}\end{array}$ & $\begin{array}{l}\text { Time in munutes } \\
\text { to travel from } \\
\text { Abobo to } \mathrm{HF}\end{array}$ & $\begin{array}{l}\text { Time in munutes } \\
\text { to travel from HF } \\
\text { to Pukedi HC }\end{array}$ & $\begin{array}{l}\text { Time } \\
\text { Gambella } \\
\text { Regional } \\
\text { Hospital }\end{array}$ & $\begin{array}{l}\text { to Time from } \\
\text { MWH in Abobo } \\
\text { to Gambella } \\
\text { Hospital }\end{array}$ \\
\hline 12 Abobo - Perbongo Omaha & 26 & 44 & 208 & 138 \\
\hline 13 Abobo - Pukedi HP & 70 & - & 208 & 138 \\
\hline $14 \begin{array}{l}\text { Abobo - Pukedi Health } \\
\text { Center }\end{array}$ & 70 & - & 208 & 138 \\
\hline $\begin{array}{l}\text { ㅇ Health Facility Name of } \\
\text { Ukuna catchment area }\end{array}$ & $\begin{array}{l}\text { Time in munutes } \\
\text { to travel from } \\
\text { Abobo to } \mathrm{HF}\end{array}$ & $\begin{array}{l}\text { Time in munutes } \\
\text { to travel from HF } \\
\text { to Ukuna } \mathrm{HC}\end{array}$ & $\begin{array}{l}\text { Time } \\
\text { Gambella } \\
\text { Regional } \\
\text { Hospital }\end{array}$ & $\begin{array}{l}\text { to Time from } \\
\text { MWH in Abobo } \\
\text { to Gambella } \\
\text { Hospital }\end{array}$ \\
\hline 15 Abobo - Ukuna HP & 31 & 3 & 129 & 138 \\
\hline $16 \begin{array}{c}\text { Abobo } \\
\text { Center }\end{array}-$ Ukuna Health & 32 & - & 127 & 138 \\
\hline 17 Abobo - Aberi & 47 & 15 & 157 & 138 \\
\hline 18 Abobo - Tierciru & 39 & 7 & 141 & 138 \\
\hline $\begin{array}{l}\mathrm{N}^{\circ} \text { Health Facility Name of } \\
\text { Mender catchment area }\end{array}$ & $\begin{array}{l}\text { Time in munutes } \\
\text { to travel from } \\
\text { Abobo to } \mathrm{HF}\end{array}$ & $\begin{array}{l}\text { Time in munutes } \\
\text { to travel from } \mathrm{HF} \\
\text { to Mender } \mathrm{HC}\end{array}$ & $\begin{array}{l}\text { Time } \\
\text { Gambella } \\
\text { Regional } \\
\text { Hospital }\end{array}$ & $\begin{array}{l}\text { to Time from } \\
\text { MWH in Abobo } \\
\text { to Gambella } \\
\text { Hospital }\end{array}$ \\
\hline 19 Abobo - Mender 8-9 & 35 & - & 89 & 138 \\
\hline $20 \begin{array}{l}\text { Abobo } \\
\text { Center }\end{array}$ & 35 & - & 89 & 138 \\
\hline $\begin{array}{ll}21 \quad \text { Abobo }- \text { Mender } 7 \\
\end{array}$ & 38 & 3 & 95 & 138 \\
\hline 22 Abobo - Mender 11-12 & 43 & 8 & 105 & 138 \\
\hline 23 Abobo - Mender 13 & 23 & 12 & 89 & 138 \\
\hline
\end{tabular}

Table 9. The table shows travel times to Gambella Hospital when pregnant women at risk for BEmONC or CEmONC are admitted well in advance at Abobo Health Center Mother Waiting Home.

\section{Discussion and conclusion}

There are no blue prints or magic bullets, which may solve the problem of delayed emergency referrals. Anyway, we might expand the coverage and reduce the gaps assuring a more equitable and performing service by adopting the mix of interventions proposed, by coupling the traditional referral with ambulance and lodging pregnant women in dedicated structures, situated in crucial settings, well in advance before the foreseen date of delivery. Of course this may have additonal costs to bear by mothers and by the referral system, but this have to be compared with the advantage in term of possible morbidity and mortality saved. Considering the resident population in the study, according to the WHO (WHO 1985), the expected pregnancies and the estimate of emergencies which may occur during pregnancies, are in the range between $5 \%$ and $15 \%$ i.e. in our case of the order of 300 . Th benefit for the Health System performance become even more evident if we consider all the other medical and surgical additional referrals that a better-organized scheme can make. Finally we stress that the main contribution of this paper is not a mere pioneering utilization of GPS or GIS and satellite images utilization in public health, as the scientific literature on the issue is very much established. The importance of this study is more linked to the fact that in Gambella Region such a kind of planning in public services, based on scientific evidence, has never been carried out. In other words this study is a preliminary work whose results could be useful for re-shaping a more efficient ambulance referral system.

\section{Acknowledgement}

We thanks for the collaboration in field works and about data elaboration: M.Amaddii (satellite image processing), C. Biffi (CUAMM Country Manager), A. Tsegaye (CUAMM Head of Program), M. Perrella (CUAMM, Administrator), A. W. Yohanis (CUAMM, Project Assistant), Ajulo Ogula (CUAMM, Midwife), Mr. Bureau Omod and Mr. Addisu Alemu (CUAMM, Public Health Nurses), Wondemagegn F. and Alemayehu A. (CUAMM, Drivers) and for the Support provided in the field by the Zonal Health Departments, Woreda Health office representatives and Head of Primary Hospitals, Health centres and the Health extension workers in each of the Health Posts. Moreover, we would like to extend our gratitude to Gambella Region Catholic Church as they have been supporting the mission in difficult areas through the provision of accommodation and transport by car and boat.

\section{References}

ArcGIS Network Analyst ${ }^{\mathrm{TM}}$, (https://desktop.arcgis.com/en/arcmap/latest/extensions/main/a bout-arcgis-for-desktop-extensions.htm)

CUAMM, MAP ATLAS, Support To Maternal and Newborn Community Health Services, Provided by First Level Health Cenres, in Gambella Region, Padua (Italy), 240 pages, 2020.

Federal Democratic Republic of Ethiopia Ministry of Health Health Sector Development Program IV2010/11 - 2014/15, FINAL DRAFT, 2010

Fogliati P, Straneo M, Brogi C, Fantozzi PL, Salim RM, Msengi HM, et al. (2015) How CanChildbirth Care for the Rural Poor Be Improved? AContribution from Spatial Modelling in Rural Tanzania. PLoS ONE 10(9): e0139460. doi:10.1371/journal.pone.0139460

Mc Lafferty SL (2003). GIS and health care: Annual review Public Health, 2003

Mc Kinnon B., Harper S., Kaufman JS, Abddullah M. (2004). Distance to emergency obstretic services and eary neonatal mortality in Ethiopia: Trop Med Int. Health, 2014

More equity and quality of health services in Gambella region, Ethiopia (http://openaid.aics.gov.it/en/iati-activity/XM-DAC6-4-010923-01-0)

Summary Pledge Progress Report Ethiopia, Version UNHCR, 2019/02.

World Health Oganization, UNFPA, UNICEF, AMDD. Monitoring emergency obstetric careç a handbook, Geneve, WHO, 2009 